\title{
À guisa de introdução: tendências recentes na tradução de poesia grega e latina no Brasil
}

João Angelo Oliva Neto

Cadernos de Literatura em Tradução neste número 15 acolhe praticamente apenas versões de poemas gregos e latinos antigos, que não tinham, todavia, deixado de comparecer em números anteriores. Aqui, os tradutores foram convidados a expor, com a detença que lhes aprouvesse, os critérios por que nortearam a tradução, fossem princípios, fossem apenas balizas práticas, ambos igualmente eficientes à tarefa, como bem sabem os que se metem nesse ofício. Portanto, quase todos aqui produziram artigos, com graus diversos de tecnicidade. A ideia era justapor concepções diferentes ao traduzir-se um conjunto de poemas "semelhantes", manifestando-se aqui a semelhança pelo fato de serem todos poemas da Antiguidade greco-latina, com os problemas comuns que oferecem não obstante a diversidade dos gêneros poéticos, da língua e da época. Mas por duas vezes houve traduções do mesmo autor, um grego, Teócrito de Siracusa, e um latino, Marcial. Outra ideia era permitir confrontar o que cada tradutor diz da tradução apresentada e quanto de fato nela faz. A crítica de tradução ainda me parece parca no Brasil e uma das razões é restringirmo-nos a discordar da estratégia que um tradutor elegeu em favor de outra que consideramos melhor. É justo e necessário fazê-lo, mas não basta. Creio que é preciso também, assumindo a proposta alheia, aferir as virtudes que tenha e quanto o tradutor a cumpre em vista dos fins que aponta, desde que esclareça a proposta e aponte os fins. Neste número, todos tiveram oportunidade de assim fazer e, conforme se verá, responderam com maior ou menor profundidade, que afinal coube ao arbítrio e à consideração de cada um.

Sete artigos são dedicados a autores gregos - Homero, Píndaro de Tebas (c. 522-c. 443 a.C.), Aristófanes (c. 446-c. 386 a.C.), Téocrito de Siracusa (acme em 270 a.C.), Lícofron de Cálcis (ativo no reinado de Ptolomeu Filadelfo 285-247 a.C.) e Luciano de Samósata (c. 120-c. 181 d.C.). Quatro artigos são dedicados a 
autores latinos - Tibulo (c. 55-c. 19 a.C.), Propércio (c. 50-c. 17 a.C.) e Marcial (c. 40 d.C-104 d.C.). Estão representados em grego o epos hínico, a lírica, a comédia, o epos bucólico, o sui generis poema de Lícofron e a oratória; em latim, a elegia e o epigrama.

Afora o relevo de cada proposta tradutória em si mesma, um aspecto significativo do volume é informar que também no Brasil já se manifesta a tendência, recente na Europa e nos Estados Unidos, de refazer metricamente em português os ritmos antigos ${ }^{1}$ e preservar com rigor a variedade métrica do autor traduzido - sua polimetria - de modo que para cada metro original passa a haver um e apenas um metro na tradução, seja tradicional, seja inventado. Agora, já não basta traduzir poemas antigos "em verso", indiferentemente, mas é preciso refazer o sentido que diferentes metros emprestam à matéria de cada poema e manter a significação maior, produzida pela polimetria mediante inter-relacionamento de poemas ou excertos de mesmo ritmo e também de ritmos diferentes, como ocorre nas tragédias e comédias, e no universo de certos livros antigos de poemas. Assim tem sido feito em dissertações e teses em Letras Clássicas nos últimos anos. Trata-se cá de constatar a tendência, não de postular que o recente é superior ao arraigado, nem que o insólito sobrepuje o costumeiro. Sabe-se que as coisas não são por força assim e, ademais, ainda não houve a crítica nem se avaliou a recepção desse modo de traduzir por parte do público maior, externo à Universidade, onde, porém, para fortuna e orgulho dos Estudos Clássicos realizados no Brasil, ocorre a maioria das traduções de textos da Antiguidade greco-romana. Em boa verdade, trazer metros antigos a línguas modernas já era multissecular na Europa quando ressurgiu na Itália no fim do século XIX com as Odi Barbare, de Giosuè Carducci, e não é inédito em Portugal nem no Brasil, como provam as Odes e Elegias de Magalhães de Azeredo (1904) e as traduções em hexâmetros portugueses que Carlos Alberto Nunes fez da Ilíada e da Odisseia na década de $1940^{2}$. Detectada a tendência que retorna, importa perceber que não é nada acidental manisfestar-se agora com mais intensidade na nova geração de tradutores de poesia grega e latina no Brasil. As razões do fenômeno hão de ser várias, entre as quais suponho esteja,

1 Outros tradutores que trazem metros antigos ao português são Rodrigo Tadeu Gonçalves et al. (coord.) "Uma Tradução Coletiva das Metamorfoses 10.1-297 com Versos Hexamétricos de Carlos Alberto Nunes", Scientia Traductionis, v. 10, pp. 110-132, 2011; Guilherme Gontijo Flores na tese Uma Poesia de Mosaicos nas Odes de Horácio: Comentário e Tradução Poética, São Paulo: DLCV/FFLCH, 2014, e Alexandre Pinheiro Hasegawa, na tese Dispositio e Distinção de Gêneros nos Epodos de Horácio: Estudo Acompanbado de Tradução em Verso, São Paulo: DLCV/FFLCH, 2010.

2 Para outros exemplos, cf. NOLASCO DA CUNHA e MAGALHÃES DE AZEREDO nas referências bibliográficas do artigo de Érico Nogueira. 
além do apreço à polimetria, a valorização do desempenho, a chamada performance, mormente de poemas arcaicos gregos, entre os egressos dos cursos de Letras Clássicas na última década. Já perdidas a música, a dança e a cantilena da récita, mas restando o metro dos antigos cantos, a esses tradutores parece que lhes dói perder também a última reminiscência do ritmo ao convertê-lo em metros próprios da poesia lusófone. No caso de latinistas, o apreço à performance contempla, além da polimetria, também o quanto determinado metro, ainda que isoladamente considerado, afeta o sentido de um poema. Subjacente à estima demonstrada aqui pelo verso métrico está o incremento de modernidade que recebeu dos próprios poetas modernistas - poetas de primeira grandeza, como Manuel Bandeira (Estrela da Tarde), Carlos Drummond de Andrade (Claro Enigma), e, mais tarde, outro, que, não morresse aos 32 anos, chegaria à mesma grandeza, Mário Faustino $(O$ Homem e Sua Hora): para eles, que foram tradutores, e para quem, compondo ou traduzindo, os toma hoje por modelo, o metro, que aliás é muito grego e muito antigo, e as sílabas ritmadas nunca foram ofício do sapo tanoeiro.

Aspecto não menos significativo foi a tendência, que a maioria absoluta dos autores revelou, de praticar nos limites disponíveis um pouco de História da Tradução de Poesia da Antiguidade em português ou ao menos no Brasil. Fizeram-no sem que lhes fosse sugerido. Uma História tal, apesar de ingente, urge começar a escrever, porque todo aquele que traduz textos antigos já traduzidos, queira ou desqueira, integra uma longa linhagem, passa a pertencer à revelia de si mesmo a um círculo bem maior e muito mais antigo do que ele, e tal condição não só lhe traz algumas responsabilidades como, decerto, the propicia um pouco de humildade. Se conhece traduções pregressas, tem modelos a imitar ou vencer, tem parâmetros para seguir ou evitar. Se as ignora, corre o risco de ficar, hoje, aquém do que já se fez outrora e pode vir a crer que inventou o que fora inventado. As traduções antigas aqui presentes não são enfeite, mas, pela reflexão que encetam, ainda que breve, funcionam, bem entendido, exercem função e intervêm nas novas propostas.

O volume começa pelos autores gregos. Carlos Leonardo Bonturim Antunes, 26 Hinos Homéricos com um hexâmetro datílico vernáculo calcado na prática de Carlos Alberto Nunes, que é matéria do último artigo do volume.

Sérgio Luiz Gusmão Gimenes Romero muito oportunamente escolheu traduzir a Olímpica I, de Píndaro, que desde a Antiguidade é apontada como que introdução de todos os poemas pindáricos. Por essa razão, não faltam em português traduções modernas e antigas do poema, entre as quais a de José Bonifácio de Andrada e Silva. Nosso patriarca já indicava as dificuldades de verter Píndaro. O poema é agora traduzido em versos livres, buscando mostrar a função ritual que a performance exerce. 
Andreza Caetano traduz d'As Nuvens, de Aristófanes, excerto do célebre debate entre a personificação do Raciocínio Justo e a do Raciocínio Injusto (vv. 889-919), mirando com a amostra propor modelo de linguagem voltada à representação teatral contemporânea e não já à recepção literária, isto é, à leitura silenciosa, que de certa forma é o que se costuma fazer na Universidade.

Rafael Brunhara verte sempre em dodecassílabos acentuados na sexta sílaba os rigorosos trímetros iâmbicos de Alexandra, de Lícofron, um dos poemas gregos mais estranhos. Afora divulgar autor pouco conhecido no Brasil, à parte o encanto da fala, sempre incrível, de Cassandra, a assim chamada "seção romana" (vv. 1226-1282) é a mais antiga narrativa que vincula o mito de Eneias ao de Rômulo e Remo, razão por que é necessária, por exemplo, para a melhor compreensão de um poema importante como a Eneida, de Virgílio.

Érico Nogueira refaz o Idílio XVI de Teócrito de Siracusa com o que chama "verso hexatônico", por reter as seis tônicas do hexâmetro datílico antigo. Refere antigas traduções portuguesas desse que foi um dos maiores poetas do Período Helenístico das letras gregas. Quanto ao poema, além de ser programático da espécie idílica do epos, inventada por Teócrito, é hino a toda poesia e clamor à proteção que ela requer.

Matías Sebastián Fernandez Robbio, autor da única tradução de texto em prosa, apresenta com brevidade o que são prolaliái ( $\pi \rho 0 \lambda \alpha \lambda \imath \alpha i ́)$ - pequenos proêmios retóricos que Luciano de Samósata escreveu para obras hoje perdidas - e traduz Héracles, notável proêmio em que a força do deus reside na língua, entenda-se, na fala, na eloquência, não já nos músculos, segundo nos mostra no texto a écfrase de uma pintura do ainda poderoso deus.

Daniel Padilha Pacheco da Costa verte o Idílio XIX do mesmo Teócrito, detendo-se igualmente em antigas traduções oitocentistas do poema, que transcreve e analisa. Na sua versão, serve-se de dístico formado por dodecassílabo acentuado na sexta sílaba e decassílabo heroico, que, conforme se verá neste volume, têm sido usual para verter elegia antiga no Brasil.

Daniel Bueno de Melo Serrano, dando início aos poetas latinos, traduziu a elegia I, 3 de Tibulo, porque apresenta o programa poético do elegista. Tibulo, aludindo, sem dizer, a passagens da Natureza das Coisas, de Lucrécio, e da Eneida, de Virgílio, que são poemas elevados, quer provar que o gênero elegíaco pode alcançar análoga elevação. Com isso, o poema é também elogio da poesia. A tradução, assim como a do outro Daniel, é feita em dísticos de dodecassílabos (metade deles acentuados na sexta sílalaba, metade alexandrinos) e decassílabos quase sempre acentuados na sexta sílaba. 
Fábio Paifer Cairolli procura distinguir nos poemas de Marcial a diferença, muito expressiva, de três metros e ritmos - dístico elegíaco, hendecassílabo falécio e coliambo - que muitas vezes é suprimida por tradutores quando empregam em português o mesmo metro para verter metros distintos. Patenteia, como passou a ser comum nos jovens tradutores, apreço à polimetria.

Alexandre Agnolon traduz do livro XIV dos Epigramas de Marcial graciosos poemas, a que chama "biblioepigramas", porque o tema deles é o antigo rolinho de papiro. Intitulado Apoforeta ("Livro das Lembrancinhas"), o livro XIV contém outros epigramas que nos sofisticados banquetes romanos acompanhavam objetos que os convidados levavam de lembrança. Para verter os dísticos elegíacos dos biblioepigramas, Alexandre Agnolon recorre ao dodecassílabo acentuado na sexta sílaba e ao decassílabo heroico e ao sáfico, como vimos ser comum; vez ou outra, produz o raro decassílabo "provençal" (ou "de gaita galega"), acentuado na quarta e sétima sílabas.

João Angelo Oliva Neto traduz as onze primeiras elegias do livro I de Propércio. Para tanto escrutina a única tradução de dísticos de elegíacos antigos que o poeta, tradutor e ensaísta Péricles Eugênio da Silva Ramos fez, forjando, conforme agora se compreende melhor, um rigoroso dístico vernáculo de alexandrino perfeito e decassílabo heroico. Depois de mostrar características rítmicas que esse dístico talvez tenha, Oliva Neto aplica-o com o rigor de que foi capaz para verter aquelas elegias de Propércio, submetendo proposta e prática à crítica de quem desejar fazê-la com isenção.

Encerra o volume entrevista de Jaa Torrano (José Antônio Alves Torrano), feita por André Malta Campos. Hoje professor-titular, o professor Torrano em 40 anos de docência na área de Língua e Literatura Grega da Universidade de São Paulo já traduziu a Teogonia (1981) e O Escudo de Héracles (2000), de Hesíodo; três poemas de Safo (1984); o canto I da Odisseia (2001); a trilogia Oresteia de Ésquilo (2004), depois todas as sete Tragédias (2009). Tendo já publicado a tradução de Bacas ("As Bacantes") e Medeia, tem no prelo traduzidas as dezenove tragédias de Eurípides. $\mathrm{Na}$ entrevista menciona professores e poetas decisivos na sua formação. Instado com argúcia pelo entrevistador, explica o papel que traduzir tem para a acurada exegese dos textos antigos, à qual chama "acribia", e como o verso livre, de raiz modernista, lhe é necessário para vertê-los. 